Vol. 9 No. 2, December 2018

\title{
PENGARUH ETIKA PEMASARAN ISLAM TERHADAP KEPUASAN NASABAH BANK SYARIAH
}

\author{
Ratna Purnama Sari*, Ahmad Mulyadi Kosim, Suyud Arif \\ Universitas Ibn Khaldun Bogor \\ *Email: purnama007@gmail.com
}

\begin{abstract}
Abstrak
Penelitian ini membahas tentang bagaimana pengaruh etika pemasaran islam terhadap kepuasan nasabah bank Syariah. Jenis penelitian ini adalah kuantitatif, dengan metode pengambilan random sampling pada seluruh nasabah BPRS Ammanah Ummah Leuwiliang. Analisis pada penelitian ini adalah regresi linear dengan alat bantu. Adapun hasil pada penelitian ini dengan nilai $p$ value $(0,000)<\alpha(0,05)$ juga membuktikan bahwa ada hubungan yang kuat antara kedua variabel tersebut. Selain itu jika dilihat dari koefisien determinasi, sebesar 57,4\% kepuasan nasabah dipengaruhi oleh etika pemasaran Islam sedangkan sisanya 42,6\% dipengaruhi oleh variabel lain yang tidak diteliti.
\end{abstract}

Kata Kunci: Etika Pemasaran Islam, Kepuasan Nasabah, Bank Syariah, BPRS Amanah Ummah.

\section{Pendahuluan}

Saat ini perbankan syariah telah memasuki persaingan berskala global, merupakan suatu tantangan yang harus dihadapi dan ditangani oleh bank syariah untuk dapat memberikan kontribusi dalam pembangunan bangsa melalui pemberdayaan ekonomi umat (Syafi'I, 2011). Ditengah eksistensi perbankan konvensional yang hanya berorientasi pada keuntungan saja, diharapkan perbankan syariah dapat menjadi alternatif dalam mencapai kesejahteraan dunia dan akhirat dengan merealisasikan nilai-nilai syariah. Selain itu, mayoritas penduduk muslim di Indonesia yang mencapai $87 \%$ menjadipotensi yang sangat besar bagi perkembangan lembaga keuangan syariah, salah satunya bank syariah.

Untuk memaksimalkan potensi diatas bank syariah dituntut melakukan berbagai upaya pembaruan terus-menerus untuk dapat bersaing dalam menarik minat nasabah. Salah satu upaya pembaruan yang dapat dilakukan bank syariah yaitu dibidang pemasaran. Pemasaran merupakan proses sosial dan manajerial untuk mencapai tujuan perusahaan dengan memperhatikan kebutuhan dan keinginan nasabah.

Peran pemasaran saat ini tidak hanya menyampaikan produk tetapi juga bagaimana produk tersebut dapat memberikan kepuasan kepada nasabah. Sasaran dari pemasaran adalah menarik nasabah baru dengan menjanjikan nilai super, menetapkan harga menarik, mendistribusikan produk dengan mudah, mempromosikan secara efektif, serta mempertahankan nasabah yang sudah ada dengan tetap memegang prinsip kepuasan nasabah (Rivai, 2012). Dengan kata lain, bidang pemasaran akan berhadapan secara langsung dengan nasabah yang mempunyai kebutuhan dan keinginan yang beraneka ragam. 
Pemasaran dituntut tidak hanya dapat memenuhi kebutuhan material tetapi juga kebutuhan spiritual nasabah. Sebagaimana konsep Islam yang tidak memisahkan materi dan spiritual tidak seperti yang dilakukan Eropa dengan konsep sekularismenya. Pada konsep sekularisme, perusahaan hanya berorientasi pada keuntungan sehingga pemasaran cenderung bersikap bebas dalam menarik minat sehingga rentan melakukan tindakan yang tidak diperbolehkan. Oleh sebab itu, kegiatan pemasaran haruslah berlandaskan pada etika. Konsep Islam memberikan kebebasan untuk mencari keuntungan sebesar-besarnya. Namun kebebasan tersebut terikat dengan iman dan etika. Etika merupakan suatu konsep nilai, baik, buruk, benar, salah dan prinsip umum yang menjadi tolak ukur boleh dan tidaknya suatu tindakan atau perilaku (Badroen, 2007).

Kegiatan ekonomi sebagaimana kegiatan lainnya perlu dituntun dan dikontrol agar berjalan sesuai dengan nilai etika dalam ajaran Islam. Nilai-nilai etika tersebut berperan sebagai regulator kehidupan guna mencegah kerusakan atau kerugian yang ditimbulkan oleh tingkah laku manusia yang cenderung egoistis. Sebagaimana Allah SWT telah mengatur etika dalam kegiatan ekonomi bagi umatnya dalam Al-Qur'an surah Asy Syu'araa' ayat 183:

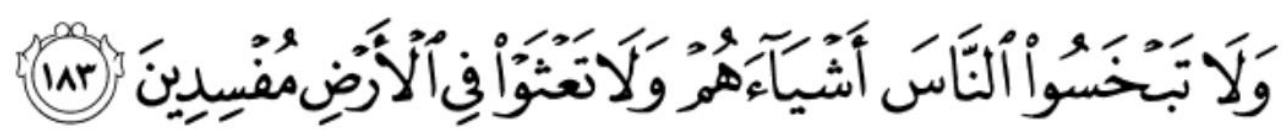

"Dan janganlah kamu merugikan manusia pada hak-haknya dan janganlah kamu merajalela di muka bumi dengan membuat kerusakan."

Dalam melaksanakan kegiatan ekonomi, Islam melarang segala perbuatan yang dapat merugikan orang lain. Begitu pula halnya dalam kegiatan pemasaran. Faktanya, pada kondisi saat ini tidak sedikit kegiatan pemasaran yang mengabaikan etika untuk menarik minat konsumen. Iklan/promosi bohong dari suatu produk banyak beredar di masyarakat yang berdampak pada kerugian pihak tertentu. Oleh sebab itu, penerapan etika dirasa penting dalam kegiatan pemasaran (Mardani, 2017).

Etika berfungsi sebagai pemberi nilai atau menetapkan perbuatan manusia (apakah termasuk perbuatan baik, buruk, mulia, hina, berguna, dan lain-lain) (Sukarno, 2013). Disini perilaku yang beretika bisa bekerja sebagai pengaman bagi organisasi/bisnis. Dengan demikian, mengadopsi etika pemasaran Islam memastikan tertanamnya benih keharmonisan dan menciptakan keadilan dalam masyarakat, sehingga meningkatkan martabat, dan menegakkan hak-hak manusia. Dengan menerapkan etika pemasaran Islam dapat menyelesaikan fungsi pemasaran dengan beretika sehingga pihak-pihak yang terkait dengan proses pemasaran tidak menjadi korban manipulasi pemasaran.

Mc Carthy mengklasifikasikan kegiatan pemasaran menjadi empat kelompok besar yang disebut 4P (Bauran Pemasaran), yaitu Product, Price, Place, dan Promotion (Adullah dan Tantri, 2015). Keempat komponen ini dianggap sebagai komponen utama pemasaran. Namun, keempat komponen tersebut dirasa belum cukup mewakili keseluruhan aspek yang terdapat dalam kegiatan pemasaran industri perbankan syariah. Mohammad Saeed menyarankan model 5P, yaitu Product, Price, Place, Promotion, dan People. Penambahan 
People dalam model tersebut mencerminkan pentingnya peran pekerja atau karyawan dalam kegiatan pemasaran (Hassan, 2008).

Pada dasarnya Islam tidak melawan semua praktik dan sistem konvensional. Namun di zaman modern ini, Islam memantau semua praktik pasar melalui proses syariah dan mengevaluasi dengan mempertimbangkan situasi dan lingkungan. Dari proses tersebut diharapkan dapat memberikan saran untuk perubahan atau perkembangan dalam isu-isu tertentu. Dalam kegiatan pemasaran bank syariah terdapat lima komponen pemasaran yang dapat dianalisis melalui lensa syariah, sehingga dapat dengan mudah mengidentifikasi komponen mana yang bertentangan dengan teori dan praktik secara syariah.

Penerapan pemasaran Islam yang menjunjung tinggi etika dapat menciptakan hubungan harmonis antara nasabah dan bank syariah, dimana hubungan kemitraan dapat dijalin secara terus menerus dalam upaya meningkatkan kepercayaan pada bank syariah. Dengan penerapan etika pemasaran Islam, diharapkan bank dapat memberikan kepuasan material maupun spiritual kepada nasabahnya.

Berdasarkan latar belakang tersebut, peneliti tertarik untuk mengambil judul "Pengaruh Etika Pemasaran Islam Terhadap Kepuasan Nasabah Bank Syariah (Studi Kasus PT. BPRS Amanah Ummah Leuwiliang-Bogor)"

\section{Tinjauan Pustaka}

\subsection{Etika Pemasaran Islam}

Dad Etika (Ethics) berasal dari kata "ethikos" (Yunani) yang bermakna "watak atau adat kebiasaan". Secara terminologis, etika merupakan kajian terhadap sistem nilai yang muncul dari tingkah laku manusia (Sukarno, 2013). Etika merupakan suatu upaya dalam merealisasikan nilai dan norma moral melalui proses penilaian atau pengajaran tentang kebaikan/keburukan dari perbuatan sehingga dapat menentukan baik atau buruk, benar atau salah, berakibat lebih baik atau lebih buruk, pantas atau tidak pantas suatu tindakan atau perilaku seseorang dalam hidupnya.

Etika ini menyangkut tentang hal yang baik dan buruk, sehingga etika mau tidak mau akan berhubungan dengan agama dan hukum. Agama merupakan sumber moral atau sumber nilai yang memberikan petunjuk kepada manusia tentang hal yang benar dan salah demi keselamatan manusia. Bahkan, untuk memaksa manusia mengamalkan tingkah laku yang baik dan menghindari yang buruk, agama sangat berperan, khususnya bagi mereka yang mengamalkan agamanya dengan baik. Sementara itu, hukum merupakan norma yang ditetapkan negara dan adat untuk memaksa manusia mengikutinya dan memberikan hukuman bagi yang melanggarnya agar tercipta ketentraman dan ketenangan manusia dalam bermasyarakat.

Jika kata "etika" tidak berdiri sendiri, melainkan dibatasi dengan penambahan kosakata "Islam" lalu menjadi "etika Islam", maka dengan sendirinya konotasinya akan megacu pada etika dan norma-norma serta ajaran Islam. Dalam hal ini tidak berbeda dari akhlak berbisnis yang dikembangkan dalam Islam (Baidan dan Aziz, 2014). 


\section{Vol. 9 No. 2, December 2018}

Yang membedakan Islam dengan materialisme ialah bahwa Islam tidak pernah memisahkan ekonomi dengan etika. Masyarakat muslim tidak bebas dalam mengelola segala sumber daya alam, mendistribusikan dan mengonsumsikannya. Ia terikat dengan akidah dan etika mulia, disamping juga dengan hukum-hukum Islam (qardhawi, 2016).

Apabila etika Islam diterapkan secara baik dan konsisten dalam berbisnis, maka semua pihak menjadi untung baik pembisnis itu sendiri, konsumen, maupun lingkungan dan pihak lain yang terlibat dalam proses bisnis tersebut. Hal itu dimungkinkan karena ciri seseorang yang mempunyai etika Islam (akhlak) itu ialah tidak melakukan sesuatu yang akan merugikan siapa pun, dirinya ataupun orang lain (Baidan dan Azizi, 2014). Manajemen bisnis semacam itulah yang perlu diterapkan dalam kegiatan pemasaran yaitu manajemen yang bernilai ibadah dan mendapatkan dua pahala dari Allah SWT yaitu di dunia dan di akhirat.

Adapun definisi pemasaran yaitu suatu sistem dalam kegiatan bisnis yang ditujukan untuk merencanakan, menentukan harga, mempromosikan, serta mendistribusikan barang dan jasa yang memuaskan kebutuhan existing customer dan potential customer.

Definisi bank syariah yaitu lembaga keuangan yang usaha pokoknya memberikan kredit dan jasa-jasa lain dalam lalu lintas pembayaran serta peredaran uang yang operasionalnya disesuaikan dengan prinsip syariah (Baidan dan Aziz, 2014).

Dari definisi tersebut dapat disimpulkan bahwa pemasaran bank syariah merupakan serangkaian kegiatan dalam merencanakan produk jasa keuangan, menentukan harga, mempromosikan dan mendistribusikan produk yang sesuai dengan kebutuhan dan keinginan nasabah, dimana keseluruhan kegiatan tersebut berlandaskan prinsip-prinsip syariat Islam.

Bank syariah sebagai lembaga keuangan yang berlandaskan prinsip syariat Islam sudah pasti dituntut untuk menerapkan etika Islam dalam kegiatan pemasarannya. Adapun nilai etika Islam tersebut seharusnya dikembalikan pada karakteristik yang sesungguhnya, yaitu sebagaimana yang dilakukan Rasulullah SAW, yaitu religius, beretika, realistis, menjunjung tinggi nilai-nilai kemanusiaan, dan tidak bertentangan dengan ajaran Islam.

Adapun beberapa nilai etika pemasaran Islam yang merujuk pada sifat Rasulullah dan prinsip etika dalam Al-Qur'an, diantaranya sebagai berikut:

\section{1) Jujur (Shiddiq)}

Artinya memiliki kejujuran dan selalu melandasi ucapan, keyakinan, serta perbuatan berdasarkan ajaran Islam. Tidak ada satu ucapan pun yang saling bertentangan dengan perbuatan. Jujur merupakan sarana mutlak untuk mencapai kebaikan tatanan masyarakat.

Pada perbankan syariah, seorang pemasar sekalipun tidak boleh melakukan kebohongan atau terlalu melebih-lebihkan atas produk yang dijual hanya demi mengejar target penjualan. Dalam kerja dan usaha, kejujuran ditampilkan dalam bentuk kesungguhan dan ketepatan waktu, janji, pelayanan, pelaporan, mengakui kelemahan serta kelebihan produk untuk kemudian dilakukan perbaikan terhadapnya.

Memelihara kejujuran akan mendorong seorang pemasar untuk berlaku adil. Keadilan diartikan dengan memberikan hak kepada seseorang yang berhak menerimanya tanpa kurang dan menerima hak tanpa lebih. Tidak seorangpun boleh mengambil alih hak orang lain secara tidak sah atau batil (Rivai, 2012). 
AL-INFAQ: Jurnal Ekonomi Islam, (p-ISSN: 2087-2178, e-ISSN: 2579-6453)

Vol. 9 No. 2, December 2018

2) Cerdas dan Bijaksana (Fathanah)

Sifat fathanah berarti mengerti, memahami, dan menghayati secara mendalam segala hal yang menjadi tugas dan kewajibannya. Fathanah menekankan kecerdasan tidak hanya keilmuan dunia tetapi juga akhirat (ajaran agama). Kecerdasan tersebut haruslah dipergunakan dengan bijaksana, tidak untuk memanipulasi orang lain tetapi sebaliknya dapat membawa kebaikan bagi orang lain.

Seorang pemasar di bank syariah selain harus paham tentang seluruh produk yang ditawarkan oleh perbankan syariah termasuk kaidah fiqhnya secara dasar, juga harus dapat menjaga amanah yang diberikan nasabah atas pembelian produk tersebut. Selain itu, pemasar dituntut berlaku adil, baik dalam pelayanan maupun penawaran harga produk kepada nasabah tanpa membedakan agama, ras, dan status sosial.

3) Dapat Dipercaya (Amanah)

Amanah memiliki makna tanggung jawab dalam melaksanakan setiap tugas dan kewajiban. Amanah ditampilkan dalam keterbukaan, kejujuran, pelayanan prima dan ihsan (berupaya menghasilkan yang terbaik) dalam segala hal.

Dalam perbankan syariah, pemasar yang memiliki sifat amanah berarti memiliki keimanan yang kuat kepada Allah di dalam dirinya. Seorang pemasar yang selalu menjaga amanah akan mendapatkan kepercayaan nasabah.

4) Argumentatif dan Komunikatif (Tabligh)

Tabligh bermakna menyampaikan, mengajak sekaligus memberikan contoh kepada pihak lain untuk melaksanakan ketentuan-ketentuan ajaran Islam. Seorang pemasar bank syariah harus memposisikan dirinya tidak hanya sebagai representasi dari perusahaan namun turut pula sebagai juru dakwah dalam pengembangan ekonomi syariah. Masih banyak masyarakat yang belum mengerti tentang ekonomi syariah, dan itulah yang menjadi tugas bagi seorang pemasar untuk menjelaskan dengan baik dan benar, sekaligus menjual produk syariah yang akan ditawarkan kepada nasabah.

5) Konsisten (Istiqomah)

Konsisten yakni bersungguh-sungguh memelihara, mempercayai, mengamalkan tuntunan-tuntunan-Nya, baik yang menyangkut prinsip ajaran maupun rinciannya, baik secara pribadi maupun penyampaiannya kepada masyarakat tanpa menghiraukan gangguan dan kecaman orang lain.

Seorang pemasar bank syariah dalam praktik pemasarannya harus selalu istiqomah dalam penerapan aturan syariah. Seorang pemasar harus dapat dipegang 


\section{Vol. 9 No. 2, December 2018}

janjinya, tidak diperkenankan seorang pemasar berubah-ubah dalam memberikan janji. Sebab dalam suatu perusahaan, konsistensi dari seorang pemasarnya menjadi cermin dari kualitas perusahaan tersebut secara keseluruhan.

Nilai etika di atas dapat diterapkan pada lima elemen yang dapat dikendalikan dalam strategi pemasaran yang disebut dengan marketing mix (bauran pemasaran). Kelima elemen tersebut diantaranya yaitu:

\section{1) Produk (Product)}

Agar suatu produk yang dibuat dapat diterima masyarakat luas sebagai pasar sasaran maka penciptaan produk harus memperhatikan kebutuhan dan keinginan nasabahnya. Produk yang diciptakan juga harus memiliki nilai lebih, keunggulan serta kelebihan dibandingkan dengan produk pesaing. Desain produk perbankan syariah berdasarkan akad yang bersumber dari prinsip muamalah (semuanya boleh, kecuali ada larangannya dalam Al-Quran dan Hadits) sehingga dapat melahirkan berbagai produk dan menjadikan bank syariah sebagai Islamic financial institution, bukan sekedar bank (beyond bank) (Ikatan Bank Indonesia (IBI), 2015)

2) Harga (Price)

Penentuan harga menjadi sangat penting untuk diperhatikan, mengingat harga menentukan laku tidaknya produk dan jasa perbankan. Harga bagi bank yang didasarkan prinsip syariah adalah bagi hasil (Kashmir, 2011). Selain bagi hasil, harga terhadap produk dan jasa bank syariah ada pula dalam bentuk margin, fee atau uang jasa (ujrah), jualah (success fee) untuk pembiayaan, penghimpunan dana, dan jasa yang diberikan.

Bagi hasil yang ditentukan dalam bentuk nisbah (proporsi bagi hasil bank dengan nasabah) tidak mutlak menentukan besarnya pembagian bagi hasil, tetapi lebih ditentukan oleh kinerja bank. Bisa saja nasabah suatu bank dengan nisbah yang lebih besar mendapat realisasi bagi hasil yang lebih kecil dari bank yang menawarkan nisbah lebih kecil.

3) Promosi (Promotion)

Promosi merupakan sarana paling ampuh untuk menarik dan mempertahankan nasabahnya. Salah satu tujuan promosi bank adalah menginformasikan segala jenis produk yang ditawarkan dan berusaha menarik calon nasabah baru. Kegiatan promosi produk dan jasa bank lebih banyak dilakukan lewat media massa cetak dan audio visual, seperti majalah, surat kabar, dan televisi. Sarana promosi yang bisa digunakan yaitu periklanan, promosi penjualan, publisitas, serta penjualan pribadi (Ikatan Bank Indonesia (IBI), 2015). 


\section{4) Distribusi (Place)}

Dalam persaingan yang ketat penentuan lokasi mempunyai pengaruh cukup signifikan dalam aktifitas menghimpun dana masyarakat serta menyalurkan pembiayaan kembali kepada masyarakat. Sebab dengan penentuan lokasi yang tepat maka target pencapaian bank akan dapat diraih. Dengan distribusi yang tepat bank dapat menjangkau masyarakat lebih maksimal.

5) Pemasar (People)

Semua orang yang terlibat aktif dalam pelayanan dapat mempengaruhi persepsi nasabah. Oleh sebab itu, layanan face to face kepada nasabah harus menampilkan karyawan yang menarik dan ramah serta memiliki kapasitas TASK (talent, attitude, skill, dan knowledge).

Pemasaran yang menerapkan nilai-nilai etika Islam akan memenuhi empat karakteristik, diantaranya yaitu:

1) Ketuhanan (rabbaniyah)

Karakteristik pemasaran Islam yang tidak dimiliki pemasaran konvensional yang dikenal selama ini adalah sifatnya yang religius (diniyyah) (Rivai, 2012). Pemasaran Islam selalu berdiri pada batas-batas yang telah ditetapkan oleh Allah SWT, menjauhi daerah yang diharamkan Allah dan semaksimal mungkin meninggalkan daerah syubhat dalam setiap kegiatannya.

Perbuatan syubhat artinya suatu wilayah yang samar-samar, atau grey area (wilayah abu-abu) yang tidak jelas halal haramnya, dengan kondisi ini seseorang mudah terjerumus ke dalam perbuatan dosa dan maksiat ((Ibdalsyah dan Tanjung, 2014). Ketidakjelasan tersebut dapat membuat hati tidak tenang dan merasa tidak aman akibat adanya keraguan yang memungkinkan terjerumus kedalam perkara yang haram.

Seorang pemasar Islami selalu meyakini bahwa hukum-hukum syariat yang bersifat ketuhanan merupakan hukum yang paling adil, sehingga akan mematuhinya dalam setiap aktivitas pemasaran yang dilakukan. Seorang pemasar Islami meskipun ia tidak mampu melihat Allah, ia akan selalu merasa bahwa Allah senantiasa mengawasinya. Penciptaan produk, penetapan harga, promosi, dan proses distribusi akan selalu memperhatikan setiap tindakan yang dilarang oleh Allah SWT yang terkandung dalam Al-Qur'an dan Hadits. Sehingga ia akan mampu menghindari segala macam perbuatan yang menyebabkan orang lain tertipu atas produk-produk yang dijualnya. Dengan konsep ini seorang pemasar Islami akan sangat hati-hati dalam perilaku pemasarannya dan berusaha untuk tidak merugikan orang lain.

\section{2) Etika (akhlaqiyyah)}

Sebagaimana yang diungkapkan oleh Yusuf Qardhawi bahwa hal yang membedakan antara sistem Islam dengan sistem agama lain adalah antara ekonomi 


\section{Vol. 9 No. 2, December 2018}

dan akhlak tidak pernah terpisah sama sekali, seperti halnya tidak pernah terpisah antara ilmu dengan akhlak, antara politik dengan akhlak dan antara perang dengan akhlak. Akhlak adalah daging dan urat nadi kehidupan Islam (Harahap, 2011).

Begitu pula dengan kegiatan pemasaran, pemasaran syariah mengedepankan masalah akhlak. Pemasaran syariah adalah konsep pemasaran yang sangat mengedepankan nilai-nilai moral dan etika tanpa peduli dari agama manapun, karena hal ini bersifat universal (Al Arif, 2012).

Ketiadaan etika dapat mengakibatkan sebuah perusahaan terjatuh, dan kehancuran yang tidak hanya berdampak pada pelakunya namun juga seluruh pihak yang terkait dengannya. Seorang pemasar syariah harus menjunjung tinggi etika dalam melakukan aktivitas pemasarannya salah satunya dengan tidak memberikan janji manis yang tidak benar serta selalu mengedepankan kejujuran dalam menjelaskan tentang kualitas produk yang sedang ditawarkan.

\section{4) Realistis (al-waqi'yyah)}

Pemasaran Islam bukanlah konsep yang ekslusif, fanatis, modernitas, dan kaku, melainkan konsep pemasaran yang fleksibel karena senantiasa mengikuti perkembangan dan kebutuhan pada zamannya yang didasarkan pada fiqh muamalah kontemporer, sebagaimana keluasan dan keluwesan syariah islamiah yang melandasinya (Rivai, 2012). Pemasaran Islami bukanlah berarti para pemasar itu harus berpenampilan ala bangsa Arab dan mengharamkan dasi. Namun pemasar Islami haruslah tetap berpenampilan bersih, rapi, dan bersahaja apapun model atau gaya berpakaian yang dikenakan.

\section{5) Humanistis (insaniyyah)}

Karakteristik humanistis berarti bahwa syariat diciptakan untuk manusia agar derajatnya terangkat, sifat kemanusiaannya terjaga dan terpelihara. Syariat Islam adalah syariat humanistis, diciptakan untuk manusia sesuai dengan kapasitasnya tanpa mempedulikan ras, warna kulit, kebangsaan, dan status. Sehingga pemasar Islami harus bersikap universal (Rivai, 2012). Setiap nasabah yang membutuhkan pelayanan bank syariah harus dilayani tanpa memandang apakah seorang muslim ataupun non muslim apakah dari status sosial yang rendah atau status sosial yang tinggi semuanya harus dilayani dalam industri perbankan syariah.

Selain itu, karakter humanistis menunjukkan posisi antara bank dan nasabah. Posisi bank dan nasabah berada pada tingkatan yang sama yaitu mitra sejajar dan posisi antara bank dan nasabah diikat oleh persaudaraan. Nasabah dalam konsep pemasaran Islam bukanlah objek belaka namun bertindak pula sebagai subyek dalam aktivitas pemasaran. Sehingga pemasar Islami sebagai ujung tombak perbankan harus mampu merangkul nasabah agar dapat menjadi kunci kemajuan bank (Al Arif, 2012). 


\subsection{Kepuasan Nasabah}

Nasabah dapat didefinisikan sebagai orang atau badan hukum yang mempunyai rekening baik rekening simpanan atau pinjaman pada pihak bank. Sehingga nasabah merupakan orang yang biasa berhubungan dengan bank atau menjadi pelanggan bank (Al Arif, 2012).

Secara umum kepuasan adalah perasaan senang atau kecewa seseorang yang muncul setelah membandingkan persepsi/kesan terhadap kinerja (atau) hasil suatu produk dengan harapan-harapannya (Rivai, 2012).

Dari definisi di atas dapat menyimpulkan bahwa kepuasan nasabah merupakan perasaan yang timbul akibat dari adanya kesesuaian antara harapan nasabah, yakni keyakinan tentang apa yang akan diterimanya apabila menjadi nasabah bank dengan apa yang diterima setelah menjadi nasabah bank.

Di era globalisasi ini, persaingan bisnis menjadi sangat tajam baik dalam tingkat nasional maupun global. Begitu pula dalam dunia perbankan. Untuk memenangkan persaingan, perusahaan harus mampu memberikan kepuasan kepada para nasabah (Supranto, 2011).

Namun tidak sedikit bank yang mengabaikan nasabah, mereka hanya dianggap sebagai sumber yang dapat menghasilkan keuntungan tanpa mempertimbangan apa yang telah diberikan, baik dari segi kualitas produk, harga, pelayanan dan aspek lain yang dapat menunjang kepuasan nasabah. Apabila hal tersebut berlangsung terus-menerus maka nasabah akan meninggalkan bank karena ketidakpuasan, dan beralih ke bank lain yang dapat memberikan produk, harga atau pelayanan yang lebih baik.

Kepuasan nasabah dalam pemasaran Islam tidak hanya muncul jika kinerja produk sesuai dengan harapan nasabah secara material, tetapi juga jika kinerja produk sesuai dengan harapan nasabah secara spiritual (Rivai, 2012). Oleh sebab itu, dalam menciptakan kepuasan pada nasabah, pemasar harus mampu menerapkan nilai etika Islam dengan maksimal dalam setiap elemen bauran pemasaran (marketing mix).

Kepuasan nasabah berlandaskan pada nilai yang telah diberikan kepada bank. Nilai ini bisa berasal dari produk, pelayanan, sistem atau sesuatu yang bersifat emosi. Jika nasabah mengatakan bahwa nilai adalah produk yang berkualitas, maka kepuasan akan terjadi jika nasabah mendapatkan produk jasa yang berkualitas. Jika nilai bagi nasabah adalah kenyamanan maka kepuasan akan datang apabila pelayanan yang diperoleh benar-benar dapat membuat nasabah tersebut merasa nyaman. Jika nilai dari nasabah adalah harga yang murah maka nasabah akan merasa puas kepada bank yang memberikan harga paling kompetitif. Atau jika nilai bagi nasabah adalah kemudahan bertransaksi, maka kepuasan nasabah akan didapat pada bank yang mampu memberikan kemudahan lebih dalam transaksi finansial yang dilakukan (Al Arif, 202). 
Menurut Kasmir (2011), ada beberapa faktor yang mempengaruhi kepuasan sehingga nasabah meninggalkan bank, sebagai berikut :

1) Pelayanan yang tidak memuaskan

Banyak hal yang menyebabkan nasabah tidak puas terhadap pelayanan yang diberikan oleh seorang customer service. Nasabah merasa tidak dilayani dengan baik, merasa disepelekan, tidak diperhatikan atau kadang nasabah merasa tersinggung.

2) Produk yang tidak baik.

Kelengkapan produk yang ditawarkan kurang sehingga pilihan yang sesuai dengan keinginan nasabah tidak tersedia. Produk yang ditawarkan tidak memiliki kelebihan atau keunggulan tertentu jika dibandingkan dengan produk yang ditawarkan pesaing.

3) Ingkar janji, tidak tepat waktu.

Petugas customer service tidak menepati janji seperti waktu pelayanan. Begitu juga dengan penyelesaian pekerjaan yang tidak sesuai dengan keinginan nasabah.

4) Biaya yang relatif mahal.

Biaya yang dibebankan kepada nasabah relatif mahal jika dibandingkan dari bank pesaing. Hal ini juga menyebabkan nasabah meninggalkan bank yang bersangkutan.

\section{Metodologi Penelitian}

Jenis penelitian yang digunakan pada skripsi ini adalah penelitian kuantitatif. Penelitian kuantitatif bertujuan untuk menjelaskan hubungan atau pengaruh yang terukur menggunakan instrumen yang telah teruji. Populasi dalam penelitian ini sebanyak 18.647 nasabah di BPRS Amanah Ummah Leuwiliang - Bogor. Dalam penarikan sampel peneliti mengacu pada teori Rao Purba sehingga didapat sebanyak 100 nasabah sebagai sampel.

Teknik sampling yang digunakan dalam penelitian ini adalah probalitas sampling, dimana setiap sampel memiliki kesempatan yang sama untuk dipilih menjadi sampel. Teknik pengambilan sampel dilakukan dengan menggunakan teknik random sampling, yaitu peneliti memilih sampel secara acak.

Pada penelitian ini teknik pengumpulan data menggunakan kuisoner (angket). Kuesioner merupakan cara pengumpulan data dengan menggunakan pertanyaan atau pernyataan tertulis untuk memperoleh informasi dari responden. Pertanyaan atau pernyataan harus dinyatakan dengan jelas dan tegas artinya hanya mempunyai satu penafsiran dan responden langsung mengerti dengan jelas apa yang ditanyakan. 
Data yang diperoleh dianalisis dengan menggunakan uji validitas, uji reliabilitas, uji univariat, uji korelasi bivariat (product moment person), uji chi-square dan koefisien determinasi. Uji validitas dan uji reliabilitas digunakan untuk menguji ke instrumen penelitian, sedangkan uji univariat, uji korelasi bivariat (product-momen person), uji chisquare dan koefisien determinasi digunakan untuk mencari hubungan dan besarnya hubungan variabel etika pemasaran Islam terhadap variabel kepuasan nasabah.

\section{Hasil Dan Pembahasan}

Identitas responden diklasifikasikan berdasarkan empat karakteristik yaitu jenis kelamin, umur, pendidikan terakhir, dan lama menjadi nasabah. Klasifikasi yang dilakukan terhadap responden dalam penelitian ini bertujuan untuk mengetahui secara jelas mengenai gambaran responden sebagai objek penelitian.

Berdasarkan karakteristik jenis kelamin, responden yang berjenis kelamin laki-laki sebanyak $42 \%$ dan yang berjenis kelamin perempuan sebanyak 58\%. Menurut klasifikasi umur, responden yang berumur 30-40 tahun 36\%, 20-30 tahun 28\%, 40-50 tahun 27\% dan kurang dari 20 tahun 9\%. Persentase responden dengan klasifikasi pendidikan terakhir tertinggi yaitu $44 \%$ yang berpendidikan SMA, $28 \%$ pendidikan Sarjana atau Diploma, 21\% SMP, 7\% pendidikan SD. Sedangkan, bedasarkan lama menjadi nasabah, responden yang lebih dari 4 tahun sebanyak 30\%, 3-4 tahun 25\%, 2-3 tahun 26\%, 1-2 tahun 6\% dan kurang dari 1 tahun $13 \%$.

Untuk mengetahui apakah terdapat hubungan antara etika pemasaran Islam dan tingkat kepuasan nasabah di BPRS Amanah Ummah sebelumnya instrumen penelitian diuji menggunakan uji validitas dan uji reliabilitas. Uji validitas digunakan untuk mengukur sah atau valid tidaknya suatu kuesioner sedangkan uji reliabilitas untuk mengetahui sejauh mana pengukuran yang telah dilakukan dalam penelitian ini dapat dipercaya atau dapat diandalkan.

Hasil uji validitas didapat dengan membandingkan nilai $r_{\text {hitung }}$ dengan nilai $r_{\text {tabel, }}$ sedangkan uji reliabilitas membandingkan nilai Cronbach's Alpha dan nilai rabel. Interpretasi dari perbandingan tersebut, jika nilai $\mathrm{r}_{\text {hitung }}$ dan Cronbach's Alpha lebih besar dari nilai $\mathrm{r}_{\text {tabel }}$ maka item pernyataan dinyatakan valid dan reliabel. Nilai $\mathrm{r}_{\text {tabel }}$ dari 100 responden yaitu sebesar 0.195 .

Berdasarkan perhitungan statistik dari data yang diperoleh menggunakan program SPSS didapat nilai $r_{\text {hitung }}$ dan Cronbach's Alpha tiap item pernyataan sebagai berikut: 
AL-INFAQ: Jurnal Ekonomi Islam, (p-ISSN: 2087-2178, e-ISSN: 2579-6453)

Vol. 9 No. 2, December 2018

Tabel 1. Hasil dan Pembahsan Uji Validitas dan Reabilitas

\begin{tabular}{|c|c|c|c|c|}
\hline Variabel & Item Pernyataan & $\mathrm{R}_{\text {hitung }}$ & Cronbach's Alpha & Keterangan \\
\hline \multirow{10}{*}{$\begin{array}{l}\text { Etika } \\
\text { Pemasaran } \\
\text { Islam (X) }\end{array}$} & Item Pernyataan 1 & 0,691 & 0,854 & Valid dan Reliabel \\
\hline & Item Pernyataan 2 & 0,428 & 0,865 & Valid dan Reliabel \\
\hline & Item Pernyataan 3 & 0,559 & 0,860 & Valid dan Reliabel \\
\hline & Item Pernyataan 4 & 0,632 & 0,857 & Valid dan Reliabel \\
\hline & Item Pernyataan 5 & 0,633 & 0,857 & Valid dan Reliabel \\
\hline & Item Pernyataan 6 & 0,459 & 0,865 & Valid dan Reliabel \\
\hline & Item Pernyataan 7 & 0,637 & 0,857 & Valid dan Reliabel \\
\hline & Item Pernyataan 8 & 0,275 & 0,870 & Valid dan Reliabel \\
\hline & Item Pernyataan 9 & 0,639 & 0,857 & Valid dan Reliabel \\
\hline & Item Pernyataan 10 & 0,533 & 0,861 & Valid dan Reliabel \\
\hline \multirow{10}{*}{$\begin{array}{l}\text { Kepuasan } \\
\text { Nasabah } \\
\text { (Y) }\end{array}$} & Item Pernyataan 1 & 0,275 & 0,871 & Valid dan Reliabel \\
\hline & Item Pernyataan 2 & 0,677 & 0,855 & Valid dan Reliabel \\
\hline & Item Pernyataan 3 & 0,549 & 0,861 & Valid dan Reliabel \\
\hline & Item Pernyataan 4 & 0,584 & 0,859 & Valid dan Reliabel \\
\hline & Item Pernyataan 5 & 0,516 & 0,862 & Valid dan Reliabel \\
\hline & Item Pernyataan 6 & 0,622 & 0,858 & Valid dan Reliabel \\
\hline & Item Pernyataan 7 & 0,350 & 0,868 & Valid dan Reliabel \\
\hline & Item Pernyataan 8 & 0,552 & 0,860 & Valid dan Reliabel \\
\hline & Item Pernyataan 9 & 0,587 & 0,859 & Valid dan Reliabel \\
\hline & Item Pernyataan 10 & 0,372 & 0,867 & Valid dan Reliabel \\
\hline
\end{tabular}

Sumber: Olah Data Peneliti

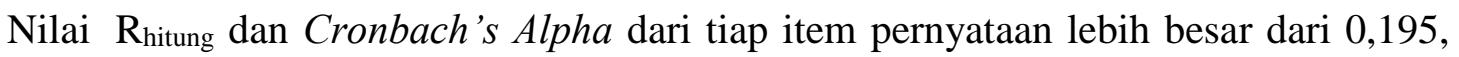
artinya terbukti bahwa tiap item pernyataan pada kuesioner penelitian dinyatakan valid dan reliabel. 


\section{Vol. 9 No. 2, December 2018}

Selanjutnya data diuji menggunakan analisis univariat. Dari hasil uji tersebut dapat diketahui bahwa $56 \%$ responden menyatakan bahwa penerapan etika pemasaran Islam di BPRS Amanah Ummah sudah sangat baik, dan 44 responden menyatakan penerapannya masih perlu dimaksimalkan lagi. Selain itu, $60 \%$ responden menyatakan sangat puas terhadap penerapan etika Islam dalam kegiatan pemasaran BPRS Amanah Ummah, namun 40\% diantaranya memiliki tingkat kepuasan yang rendah.

Untuk mengetahui angka indeks korelasi antara etika pemasaran Islam (variabel $\mathrm{x}$ ) dan kepuasan nasabah (variabel y), maka maka data diolah menggunakan perhitungan korelasi bivariat (product moment person). Dari perhitungan tersebut diperoleh nilai koefesien $r_{x y}$ sebesar 0.758 .

Interpretasi terhadap $r_{x y}$ dapat di tempuh dengan cara interprestasi sederhana. Dari perhitungan di atas telah diperoleh $r_{x y} 0.758$, jika dilihat dari tabel interpretasi maka angka indeks korelasi $(0,758)$ terletak antara 0,70 - 0,90. Artinya, dapat dinyatakan bahwa ada pengaruh yang kuat antara etika pemasaran Islam terhadap kepuasan nasabah. Untuk memperkuat interpretasi tersebut dilakukan uji chi-square. Hasilnya diperoleh nilai $\rho$ sebesar 0,000, yaitu lebih kecil dari nilai standar signifikasi $(0,05)$. Sehingga dapat dinyatakan terdapat hubungan yang kuat dari dua variabel tersebut.

Kemudian untuk mengetahui besarnya persentase pengaruh variabel etika pemasaran Islam terhadap kepuasan nasabah di BPRS Amanah Ummah dilakukan uji koefisien determinasi. Pengujian tersebut menunjukkan nilai R Square sebesar 0,574, jika diubah dalam bentuk persentase maka diperoleh 57,4\%. Maka dapat disimpulkan bahwa kepuasan nasabah di BPRS Amanah Ummah dipengaruhi oleh etika pemasaran Islam sebesar 57,4\%, sedangkan sisanya $42,6 \%$ dipengaruhi oleh variabel yang tidak diteliti dalam penelitian ini.

Adapun beberapa kesimpulan yang berdasarkan uji frekuensi sebagai berikut:

1) Responden mengakui bahwa produk yang ditawarkan BPRS Amanah Ummah sesuai dengan syari'at Islam, bebas dari riba dan transaksi yang dilarang Islam. Hasil jawaban responden menunjukkan 20,0\% menyatakan sangat setuju dan 68,0\% responden menyatakan setuju. Hal ini menggambarkan bahwa etika pemasaran Islam pada produk sudah sesuai dengan syari'at islam.

2) Responden mengakui bahwa BPRS Amanah Ummah tidak ingkar janji dalam menjalankan produk sesuai dengan akad yang telah dipilih nasabah. Jawaban responden menunjukkan $52.0 \%$ menyatakan sangat setuju dan $48.0 \%$ responden menyatakan setuju. Hal ini menggambarkan bahwa BPRS Amanah Ummah menjaga amanah dalam menjalankan akad produk yang dipilih nasabah.

3) BPRS Amanah Ummah menetapkan biaya administrasi yang terjangkau bagi semua nasabah, jawaban responden menunjukkan $13,0 \%$ menyatakan sangat setuju dan $67.0 \%$ responden menyatakan setuju. Hal ini menggambarkan bahwa etika pemasaran Islam dalam penetapan harga sudah bagus namun masih belum sangat 


\section{Vol. 9 No. 2, December 2018}

memuaskan karena hasil responden yang menyatakan sangat setuju lebih sedikit daripada responden menyatakan setuju.

4) BPRS Amanah Ummah menetapkan bagi hasil yang saling menguntungkan bagi bank maupun nasabah, jawaban responden menunjukkan $44.0 \%$ menyatakan sangat setuju dan $53.0 \%$ menyatakan setuju. Hal ini menggambarkan bahwa bagi hasil yang diberikan oleh bank sudah dirasa adil bagi nasabah.

5) BPRS Amanah Ummah melakukan promosi (brosur, iklan, dll) dengan jujur sesuai dengan fakta produk yang ditawarkan, jawaban responden menunjukkan $42.0 \%$ menyatakan sangat setuju dan $55.0 \%$ menyatakan setuju, hal ini menggambarkan bahwa promosi yang dilakukan sudah menerapkan etika Islam yaitu menjaga kejujuran.

6) Promosi BPRS Amanah Ummah tidak mengandung kata-kata/gambar yang tidak sopan/melanggar syariat Islam, jumlah responden menunjukkan $51.0 \%$ menyatakan sangat setuju dan $48.0 \%$ menyatakan setuju, hal ini menggambarkan bahwa BPRS Amanah Ummah memperhatikan aturan Islam dalam menarik minat nasabah.

7) BPRS Amanah Ummah memproses produk yang dipilih nasabah dengan cepat dan tepat, jumlah responden menunjukkan $46.0 \%$ menyatakan sangat setuju dan $52.0 \%$ menyatakan setuju, hal ini menggambarkan bahwa prosedur BPRS Amanah Ummah tidak bertele-tele dan memperhatikan kepentingan nasabah.

8) Karyawan BPRS Amanah Ummah menguasai dan memahami pengetahuan tentang produk yang ditawarkan, jumlah responden menunjukkan $41.0 \%$ menyatakan sangat setuju dan $58.0 \%$ menyatakan setuju, hal ini menggambarkan bahwa dalam memasarkan produk karyawan telah menguasai pengetahuan tentang produk dengan baik.

9) Karyawan BPRS Amanah Ummah tidak melebih-lebihkan produk untuk menarik minat nasabah, jumlah responden menunjukkan $27.0 \%$ menyatakan sangat setuju dan $64.0 \%$ menyatakan setuju. Hal ini menggambarkan bahwa karyawan bersikap apa adanya dalam menawarkan produk.

10) Karyawan BPRS Amanah Ummah tidak menyembunyikan kekurangan produk dari nasabah, jumlah responden menunjukkan $29.0 \%$ menyatakan sangat setuju dan $65.0 \%$ menyatakan setuju. Hal ini dinyatakan bahwa dalam memasarkan produk karyawan BPRS Amanah Ummah selalu berlaku jujur.

\section{Kesimpulan Dan Saran}

\subsection{Kesmpulan}

Berdasarkan hasil pembahasan dan analisa data yang telah dilakukan, maka dapat dikemukakan beberapa temuan sebagai berikut :

1. Terdapat pengaruh antara etika pemasaran Islam terhadap kepuasan nasabah bank syariah. Mengedepankan nilai-nilai etika pemasaran Islam seperti shiddiq, fathanah, amanah, tabligh, dan istiqomah dalam perencanaan produk, penetapan harga, promosi, distribusi dan orang (pemasar) secara signifikan dapat mempengaruhi tingkat kepuasan nasabah di BPRS Amanah Ummah. 
2. Berdasarkan hasil uji korelasi bivariat (Product-moment Person) diperoleh nilai korelasi sebesar 0,758 dan hasil uji chi-square diperoleh nilai $\mathrm{p}=0,000$, sehingga $\mathrm{p}<\mathrm{a}(0,05)$. Dari kedua hasil uji tersebut, dapat dinyatakan ada pengaruh yang kuat antara etika pemasaran Islam dengan kepuasan nasabah. Selain itu, berdasarkan uji koefisien determinasi menunjukkan bahwa kepuasan nasabah dipengaruhi oleh etika pemasaran Islam sebesar 57,6\%.

\subsection{Saran}

Berdasarkan hasil wawancara dan jawaban pada kuesioner, masih ada responden yang belum paham dengan produk-produk syariah di BPRS Amanah Ummah Leuwiliang-Bogor. Akan lebih baik jika promosi bank dapat memberikan informasi yang lebih lengkap tentang produk yang ditawarkan.

Peneliti menyarankan agar setiap karyawan menyampaikan kelebihan maupun kekurangan setiap produk syariah yang diminati calon nasabah karena masih banyak nasabah yang bersikap pasif dalam bertanya.

Peneliti menyarankan agar BPRS Amanah Ummah mengembangkan distribusi lebih luas dengan tersedia lebih banyak kantor kas untuk mempermudah nasabah dalam bertransaksi.

\section{Referensi:}

Abdullah, T, et al.(2015), Manajemen Pemasaran, Jakarta: Rajawali Pers.

Abul Hassan, Abdul Latif S. (2008). Islamic Marketing Ethics and Its Impact on Customer Satisfaction in the Islamic Banking Industry. JKAU: Islamic Economics, Vol. 21, No. 1.

Al Arif, M. Nur Rianto. (2012). Dasar-Dasar Pemasaran Bank Syariah, Bandung: Alfabeta.

Antonio, Muhammad Syafi'i. (2011). Bank Syariah; Dari Teori ke Praktik, Jakarta: Gema Insani.

Arikunto, Suharsimi. (2013). Prosedur Penelitian: Suatu Pendekatan Praktik, Jakarta: Rineka Cipta.

Baidan, Nasrudin, et al. (2014). Etika Islam dalam Berbisnis, Yogyakarta: Pustaka Pelajar.

Badroen, Faisal, et al. (2007). Etika Bisnis Dalam Islam, Jakarta: Kencana.

Harahab, Sofyan S. (2011). Etika Bisnis dalam Perspektif Islam, Jakarta: Salemba Empat.

Ibdalsyah dan Tanjung, H. (2014). Fiqh Muamalah, Bogor: Azam.

Ikatan Bankir Indonesia (IBI), (2015). Strategi Bisnis Bank Syariah, Jakarta: Gramedia.

Ismail. (2014). Perbankan Syariah, Jakarta: Kencana.

Kasmir. (2011) Manajemen Perbankan, Jakarta: Rajawali Pers.

Kotler, P. (2000). Manajemen Pemasaran, Jakarta: Indeks.

Mardani. (2017). Ayat-Ayat Dan Hadits Ekonomi Syariah, Jakarta: Rajawali Pers.

P3EI. (2009). Ekonomi Islam, Jakarta: Rajawali Pers.

Qardhawi, Yusuf,. (2016). Norma dan Etika Ekonomi Islam, Jakarta: Gema Insani.

Rakhmat, Jalaluddin dan Idi Subandy Ibrahim. (2016) Metode Penelitian Komunikasi, Bandung: Simbiosa Rekatama Media.

Rivai, Veitzal. (2012). Islamic Marketing, Jakarta: Gramedia.

Shihab, M. Quraish (2007). Tafsir Al-Nishbah, Jakarta: Lentera Hati. 
AL-INFAQ: Jurnal Ekonomi Islam, (p-ISSN: 2087-2178, e-ISSN: 2579-6453)

Vol. 9 No. 2, December 2018

Soemitra, A. (2014). Bank Dan Lembaga Keuangan Syariah, Jakarta: Kencana, 2014.

Sugiyono. (2011). Metode Penelitian Kuantitatif, Kualitatif, Dan Kombinasi (Mixed Methods), Bandung: Alfabeta.

Sukarno, F. (2013). Etika Bisnis dalam Perspektif Ekonomi Islam, Bogor: Al Azhar Freshzone Publishing.

Sunyoto, D. (2013). Manajemen Pemasaran, Yogyakarta: CAPS.

Supranto. (2011). Pengukuran Tingkat Kepuasan Pelanggan, Jakarta: Rineka Cipta, 2011.

Tanjung, H, \& Devi, A. (2013). Metodologi Penelitian Ekonomi Islam, Bekasi: Gramata Publishing, 2013.

Tanjung, H. (2016) . 50 Pertanyaan Seputar Ekonomi Islam, Bogor: UIKA Press, 2016.

Wirdyaningsih, et al,. (2007). Bank dan Asuransi Islam di Indonesia, Jakarta: Prenada Media. 